\title{
Climate Change Impacts and Adaptation Strategies of Agriculture in Mediterranean-Climate Regions (MCRs)
}

\author{
Alejandro del Pozo ${ }^{1, *}$, Nidia Brunel-Saldias ${ }^{1}$, Alejandra Engler ${ }^{2,3}$, Samuel Ortega-Farias ${ }^{4}(\mathbb{D}$, \\ Cesar Acevedo-Opazo ${ }^{4}$, Gustavo A. Lobos ${ }^{1}$ (D), Roberto Jara-Rojas ${ }^{2,3}$ and \\ Marco A. Molina-Montenegro 5,6 \\ 1 Plant Breeding and Phenomic Center, Faculty of Agricultural Sciences, University of Talca, \\ Talca 3460000, Chile; nidiabrunel@gmail.com (N.B.-S.); globosp@utalca.cl (G.A.L.) \\ 2 Department of Agricultural Economics, Faculty of Agricultural Sciences, University of Talca, \\ Talca 3460000, Chile; mengler@utalca.cl (A.E.); rjara@utalca.cl (R.J.-R.) \\ 3 Millennium Nucleus CSIEP, University of Talca, Talca 3460000, Chile \\ 4 Research and Extension Center for Irrigation and Agroclimatology (CITRA), University of Talca, \\ Talca 3460000, Chile; sortega@utalca.cl (S.O.-F.); cacevedo@utalca.cl (C.A.-O.) \\ 5 Molecular and Functional Ecology Center, Institute of Biological Sciences, University of Talca, \\ Talca 3460000, Chile; marco.molina@utalca.cl \\ 6 Center for Advanced Studies in Arid Zones (CEAZA), Catholic University of the North, \\ Antofagasta 3580000, Chile \\ * Correspondence: adelpozo@utalca.cl
}

Received: 11 April 2019; Accepted: 13 May 2019; Published: 15 May 2019

\begin{abstract}
The world's five Mediterranean-climate regions (MCRs) share unique climatic regimes of mild, wet winters and warm and dry summers. Agriculture in these regions is threatened by increases in the occurrence of drought and high temperature events associated with climate change (CC). In this review we analyze what would be the effects of CC on crops (including orchards and vineyards), how crops and cropping and farming systems could adapt to $\mathrm{CC}$, and what are the social and economic impacts, as well as the strategies used by producers to adapt to CC. In rainfed areas, water deficit occurs mostly during the flowering and grain filling stages (terminal drought stress), which has large detrimental effects on the productivity of crops. Orchards and vineyards, which are mostly cultivated in irrigated areas, will also be vulnerable to water deficit due to a reduction in water available for irrigation and an increase in evapotranspiration. Adaptation of agriculture to CC in MCRs requires integrated strategies that encompass different levels of organization: the crop (including orchards and vineyards), the cropping system (sequence of crops and management techniques used on a particular agricultural field) and the farming system, which includes the farmer.
\end{abstract}

Keywords: agronomic practices; crops; farmer adoption; functional symbiosis; genetic improvement; water deficit

\section{Introduction}

There are five Mediterranean-climate regions (MCRs) in the world (the Mediterranean basin, California, Central Chile, the Cape Region of South Africa, and the southernmost regions of Australia) that share mild wet winters and warm and dry summers. As a whole they represent $2 \%$ of the Earth's land surface, contain $20 \%$ of the world's plant species, and are inhabited by about $5 \%$ of the world's population. The percentage of agricultural land ranges from $6 \%$ in California to $37 \%$ in Australia and reaches $55 \%$ in the central valley of Chile [1]. Farming systems in MCRs cover a large variety of crops, the most relevant and distinct being cereals, pulses and pastures in rainfed areas, and orchards and vineyards that are mostly under irrigated conditions and intensive productive systems. 
Agriculture in MCRs is threatened by increases in the occurrence of drought and high temperature events associated with climate change (CC) [2,3]. In semi-arid zones the instability of water resources will not only be detrimental to crop productivity but will also generate substantial socioeconomic impacts [4]. Adaptations of crops (including annual crops, vegetables, orchards, and vineyards), cropping systems, which are understood as the sequence of crops and management techniques used on a particular agricultural field [5], and farming systems will be necessary to overcome the vulnerability of MCRs to CC (Figure 1). Adaptation implies a process of adjustment to the climate and its current or expected effects in order to moderate or avoid negative impacts or take advantage of the beneficial effects. A wide range of technological approaches is available to improve the adaptation of crops and farming systems to CC. However, technological demands as well as extension and training approaches need to be further evaluated to better understand the role of technology in adaptation [6]. In light of the Paris Agreement in 2015, 173 countries agreed to strengthen the ability to withstand the impacts of CC by providing financial flows, developing technology and enhancing capacities of the agricultural sector, among which adaptation occupies an important part of the agenda [7]. This effort requires a multidisciplinary approach in which agronomists, physiologists, breeders and molecular biologists, sociologists, economists and other social sciences contribute with specific tools to understand complex farming systems in regions where the threat of $\mathrm{CC}$ is placing the future of sustainable agriculture at risk [8].

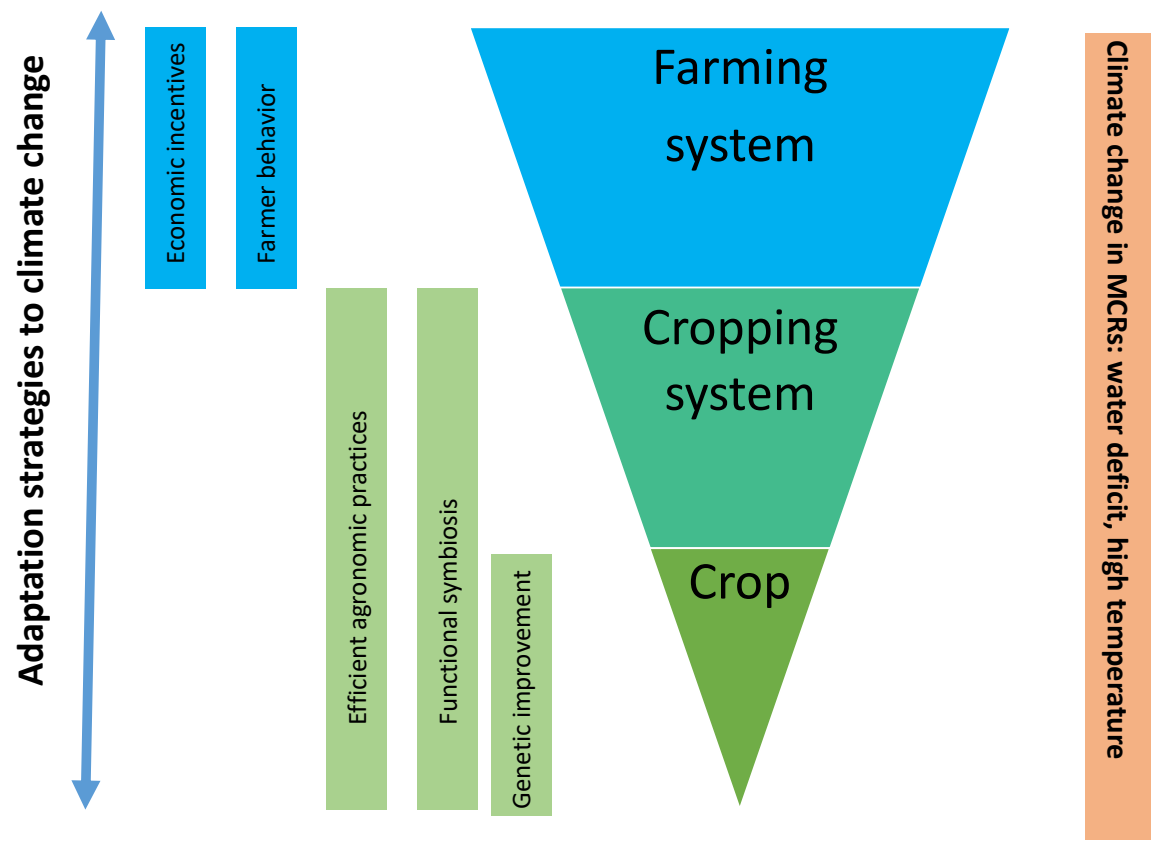

Figure 1. Schematic representation of adaptation strategies of agriculture to climate change in Mediterranean-climate regions (MCRs).

The purpose of this review is to analyze the effects of CC in MCRs and how technologies can contribute to the adaptation of major crops, orchards and vineyards to maintain food security and agricultural sustainability (economic, environmental and social dimensions). In addition, we analyze the economic and social perspectives associated with CC. This paper aims to tackle the following questions: what changes in environmental conditions are expected in MCRs as a consequence of CC, and what will be the effects on annual crops, orchards and vineyards? How can crops and the cropping and farming systems in MCRs adapt to CC? What are the social and economic impacts of CC and strategies used by producers to adapt to CC? These questions are addressed in three sections: the CC effects on Mediterranean agriculture; adaptation of agriculture to CC and; economic and social impacts, and producer adaptation. 


\section{Climate Change Effects on Mediterranean Agriculture}

The main characteristic of the MCRs is the concentration of rains into a short period of time during the year, which in the case of California and Chile occurs during four months in winter when nearly $80 \%$ of the precipitation falls. In addition, precipitation in MCRs presents large intra and interannual variability associated with climate oscillation phenomena like the North Atlantic Oscillation (NAO) and East Atlantic (EA) pattern that affect the Mediterranean basin [9], and the El Niño-Southern Oscillation (ENSO) that affects central Chile and southern Australia [10].

There is evidence that precipitation has decreased and temperatures increased in MCRs over the last century, which are probably associated with CC [11-14]. In addition, most climate models forecast further decreases in precipitation and temperature increases in MCRs by the end of the 21st century $[2,15,16]$. Another study predicted that the frequency of winter precipitation would decrease in MCRs, although extreme rainfall would increase in some areas [4]. These changes in the amount and distribution of rainfall, together with high evapotranspiration during spring and summer, will increase water deficit over prolonged periods of time in the MCRs.

The environmental constraints associated with CC will not only reduce the yield and quality of crops [17,18], orchards [19,20], and vineyards [21], but will also affect the distribution and planted area of many crops.

\subsection{Effects of Water Deficit on Seed/Fruit Growth, Yield and Quality}

Drought stress has a great impact on the yield of major crops [22]. In rainfed areas in the MCRs and semi-arid tropics, annual crops like cereals and legumes are exposed to a progressive water deficit during the flowering and grain filling stages, leading to what has been called 'terminal drought stress' [23-25] for cereals; [26] for grain legumes). The water deficit during these phenological stages reduces leaf photosynthesis and the production of photosynthetic assimilates that are directly transferred to the grain [27]. As a consequence, the number of grains per spike/pod is strongly reduced and so is grain weight, but to a lesser extent, all leading to lower grain yields [25,26]. The harvest index, i.e. the proportion of aboveground biomass distributed to the grain, also decreases under terminal drought stress [28]. In cereals, the assimilates necessary for grain growth are not only provided by photosynthesis in the leaves, but also by the photosynthetic activity of the spike $[29,30]$ and the remobilization of stored reserves in stems during the pre- and/or post-anthesis periods [31-34]. Thus, under terminal drought stress when the photosynthetic activity of the leaves declines, the contribution of stem reserves (mainly water soluble carbohydrates; WSCs) to the grain is of great importance [25,32]. In legumes, the reserves in vegetative organs (stems and roots) are also remobilized to the grain and play an important role in sustaining grain yield under terminal drought [26,35].

In irrigated lands in most MCRs, the water available for irrigation is diminishing due to frequent drought and strong competition for water resources among agriculture, industry and urban areas. On the other hand, higher temperatures increase evapotranspiration and therefore the irrigation requirements of the crops [19]. Thus, the challenge is to reduce the amount of water used for irrigation, but doing so with the lowest negative impact on seed/fruit yield and quality. It is well known that the effects of water deficit on seed/fruit yield and quality are highly dependent on the development stage of the crops. In general, the reproductive and seed/fruit growth stages are more sensitive to water deficit than the vegetative or maturity stages. For instance, in maize, water deficit during silking-pollination (R1 stage) and blister (R2 stage) stages reduces seed set and increases grain abortion, causing major yield loss [36]. In orchards, water deficit during flowering and the fruit-growth stages usually causes greater reduction in fruit yield than reductions close to the fruit maturity stage [37,38]. In grapevine (cv. Sultanina), water deficit imposed between bud break and flowering caused more reduction in yield than deficits applied between the pea size and ripening stages [39]. In addition, the effects of water deficit on fruit growth and quality depend on the severity and duration of the stress [40-42]. Severe water stress reduces fruit yield and quality, but mild water deficits can have positive effects on fruit quality $[43,44]$. 
A better use of the water available from rainfall and irrigation should be a priority in MCRs, in order to increase water productivity (WP), defined as the yield per unit of water used in evapotranspiration [23,45]. This can be achieved through the development of better-adapted cultivars, together with the implementation of efficient agronomic practices and irrigation techniques, which are described in Section 3.

\subsection{Effects of High Temperatures on Yield and Quality}

Temperature is expected to increase by $2-4{ }^{\circ} \mathrm{C}$ in MCRs by the middle of the 21st century [13]. High temperatures can affect a number of physiological and metabolic processes, influencing plant development, growth, and productivity. There is evidence that the increase in temperatures associated with CC may reduce the yield and quality of crops $[17,46,47]$. Even moderate increases in temperature accelerate plant development, reducing the growing period and plant biomass, probably as a consequence of changes of phenological dates, length of crop seasons, and crop water requirements $[48,49]$. Locations with already warm spring and summer seasons (severe scenario, up to $4{ }^{\circ} \mathrm{C}$ ) will see yield reductions if temperatures and evapotranspiration increase [50]. However, in cases where temperature limits the length of the growing season, warmer conditions (moderate scenario, up to $2{ }^{\circ} \mathrm{C}$ ) might be beneficial to crop yields [50,51].

The projected increase in extreme weather events (e.g., periods of high temperature and droughts) especially in the MCRs of Europe will increase yield variability [52-55]. Simulation studies indicate that grain yields of corn, sorghum and wheat will increase under equivalent doubling of atmospheric $\mathrm{CO}_{2}$ levels and upon addition of $2{ }^{\circ} \mathrm{C}$ to the mean daily air temperature, and will decrease when the mean daily air temperature increases by $4{ }^{\circ} \mathrm{C}$, as compared with the baseline climate yield $[50,51,56]$. Also, higher temperatures increase the accumulation of growing degree days and reduce chilling hours during wintertime dormancy, both affecting the flowering time of temperate fruit trees [57-59]. In the case of vineyards, future temperature increases may change the timing of grape ripening and the harvest date, and may affect yield and the quality of grapes and wine [21,60,61].

\section{Adaptation of Agriculture to Climate Change}

The adaptation of agriculture in MCRs should be a priority for improving crop performance and resilience to environmental constraints. Indeed, the predicted scenarios for CC, leading to higher temperatures and water deficit, will impose severe limitations on crop yield and harvested area $[18,47,62]$, and will restrict the latitudes and soils where economically important species can be grown. Adapting agriculture to CC requires integrated strategies that encompass different levels of organization: the crop (including orchards and vineyards), the cropping system (sequence of crops and management techniques used on a particular agricultural field) and the farming system, which includes the farmer (Figure 1). The adaptation strategies for crops and cropping systems include genetic improvement [28], i.e. the development of new cultivars with high yield potential and better adaptation to water deficit conditions and high temperatures; the use of efficient agronomic practices in rainfed and irrigated areas [63-65], and; exploring functional symbiosis between plants and microorganisms [66], which can produce plants with greater tolerance to abiotic stresses (Figure 1). At the farming system level, the adaptation strategies include farmer behavior and economic incentives (Figure 1). While plant breeding is a long-term process that directly addresses the problem [67], agronomic practice is the most immediate strategy, but also strongly influenced by CC [18]. On the other hand, influencing farmer behavior towards adopting new practices can be addressed in the short- and long-run by designing appropriate economic incentives.

\subsection{Genetic Improvement for Changing Environments}

Most cultivars of the current crops have been selected under conditions of high resource input and this selection has been extremely successful. However, the environmental constraints on crops as a consequence of CC in MCRs highlight the necessity of developing new cultivars with high yield potential and better adaptation to water-limiting conditions and high temperatures. 
Genetic improvement is the science of applying genetic and plant breeding principles as well as physiology and biotechnology to improve crops for human use. Traditionally, genetic improvement has been mainly based on empirical selection of crop yield (and quality). However, this methodology is not optimal because yield is a character with low heritability and high genotype $(G) \times$ environment (E) interaction [68]. Unfortunately, due to the large number of genotypes to be evaluated, traditional breeding has not been able to address the challenge of deep phenotype characterization [69], which has also represented a significant limitation in the understanding the $G \times E$ interaction [70-73]. The scenario is even more complex if agronomic management $(\mathrm{M})$ is considered as a third influential factor, which would make it even more difficult to understand this complex interaction in the field $(G \times E \times M)$ [74].

Although the relationship between genotype and phenotype has been studied for over 20 years, the results show that researchers are still far from fully understanding this 'black box' [75]. This has forced breeders to continue using traditional methodologies, focused on the evaluation of various visual characteristics (plant height, resistance to diseases, growth habit, date of bloom and harvest, etc.) and a few that require measurements of moderate complexity (yield and its agronomic components, grain or fruit quality, etc.). This approximation not only leaves aside traits that might be relevant for plant improvement under adverse conditions, but also jeopardizes the understanding of $\mathrm{G} \times \mathrm{E}$ or $\mathrm{G} \times \mathrm{E} \times \mathrm{M}$.

There is evidence that an analytical or indirect selection methodology, based on comprehension of crops at the physiological and molecular level, may help to identify key features that limit crop yield [72,76-79]. Most of the stress tolerance-related traits are complex because many genes are involved [28,80-82]. This highlights the urgency of developing technologies and methodologies that could facilitate understanding of the vulnerability or adaptation of a genotype in a given environment, contributing at the same time to improving the predictive capacity of marker-assisted breeding $[67,70,79,83]$. Hence, in order to develop cultivars well adapted to environmental fluctuations or constraints, breeders will be forced to evaluate the maximum number of possible traits that allow characterization of a genotype's performance under different conditions. The only way to satisfy all these demands is through the use of high-dimensional phenotypic data (high-throughput field phenotyping) or "Phenomics" [84]. This new approach would allow a reduction in breeding program costs [85] and, by allowing the early selection of genetic material of interest, increase the chances of releasing more cultivars [86] and in a shorter time [20,67].

In addition, biotechnological tools can be used to help crop adaptation to climate and socioeconomic changes. However, genetically-modified plants are still not accepted in some countries of the MCRs (e.g., most of the European countries, Chile) because GMOs are considered a technology with high potential risk for the people and the environment.

\subsection{Efficient Agronomic Practices}

Efficient agronomic practices should focus on preventing further degradation of soil and water resources [87] and maximizing the use of available water, according to the type of agriculture. Indeed, a number of agronomic practices are available for rainfed and irrigated production systems.

In rainfed areas of MCRs, the amount of soil water available for the crop during grain filling is the main limiting factor for yield. Thus, the distribution of rainfall in spring and early summer could be even more important than the total amount of precipitation during the growing season [88,89]. Also, soil properties (texture, porosity, organic matter, impeding layers in the soil profile, among others), tillage systems and crop residue management that promotes water infiltration and accumulation in the soil are of great importance for the effective use of water during drought periods [90,91]. Conservation tillage systems, like zero-tillage or minimum tillage, are good options to increase soil water retention and crop productivity under water-limited conditions [91-94]. In fact, higher crop yields have been reported under conservation compared with conventional tillage in drier years [92,94-96]. The amount of crop residue on the soil surface is also relevant for increasing soil water availability because it reduces the incident solar radiation and decreases soil evaporation [49]. Other management practices such as adjustment of sowing dates, the use of better adapted cultivars and water harvesting systems 
can provide more access to water at critical stages and a better synchronization between crop water demand and soil water availability [65,97]. However, many of these agronomic practices need to be adjusted to local hydrological conditions and to the socio-economic reality of farmers [65].

In irrigated lands, the instability of water resources will not only be detrimental to crop productivity, but can also generate substantial socioeconomic impacts [4]. In this regard, agricultural water management is shifting from an emphasis on production per unit soil area towards maximizing water productivity (production per unit of consumed water) [45]. Over $80 \%$ of the agricultural production in the Mediterranean basin comes from irrigated areas, and this is why it is essential to improve irrigation efficiency to continue satisfying the future demand for food $[98,99]$. To tackle the low irrigation efficiency observed in many countries within the MCRs it will be necessary to improve water transport infrastructure to reduce water losses, improve irrigation system distribution and on-farm application, and adopt irrigation-efficient technology [100].

Consideration must be given not only to the total seasonal water available in a region but also to when water deficits are likely to occur so as to adjust water needs to the available resources and use limited water supplies in the most effective way [101]. Strategies such as a) regulated deficit irrigation b) site-specific irrigation management and c) modification of the microclimatic conditions (using shading nets, plastics cover, and mulch) can be applied to increase water productivity, yield, and quality [102]. Although there are several technical alternatives to implement efficient irrigation systems, the main limiting factor will be the capacity of the region or the farmer to invest in irrigation [99]. Also, adaptation strategies could include the replacement of crops with significant water needs, such as maize or fruit trees, with others (annual or perennial) that have lower or no irrigation demands [103].

\subsection{Functional Symbiosis}

Functional symbiosis, defined as the permanent association between two or more specifically distinct organisms, at least during a part of the life cycle, is an ancient biological phenomenon known to be a ubiquitous and important aspect of life on Earth. Most studies do not consider the fact that all plants in natural ecosystems or agroecosystems are thought to be symbiotic with microbial organisms, which has profound effects on plant performance and productivity under stress environments [104]. Recently, it has been reported that fungi in symbiosis with plants can also act as conduits for signaling between plants, even between plants of different species, acting as an early warning system or network for environmental constraints [105].

The continuity of microbial associations with plants suggests that plants do not function as autonomous individuals, but their internal tissues provide a unique ecological environment for diverse communities of symbiotic microbes, which have had a major influence on plant productivity [106,107]. Several studies indicate that benefits conferred by mutualistic fungi contribute to or are responsible for plant adaptation to environmental stress [108]. Mutualistic fungi may confer tolerance to drought, heavy metals, disease, heat and plagues, and/or promote growth and nutrient acquisition, and improve water use efficiency $[109,110]$. Thus, in agreement with the current literature, it is important to consider functional symbiosis (plants associated with microorganisms) as part of a broader approach to study the adaptive responses of Mediterranean agriculture under stressful environments. Moreover, it is necessary to explore the nature of functional symbioses under future scenarios imposed by CC such as increased desertification in MCRs.

Functional symbioses in turn pose fewer risks to human health, have little or no residual effects, and they possess low risks with positive impacts for yield and environmental tolerance, having already been accepted in organic farming [111]. Therefore, there is plenty of room for research and development of novel microorganisms for pest management and for increasing plant environmental tolerance. Indeed, research on functional symbioses that produce plants with greater tolerance to new environmental challenges, such as those imposed by CC, is also expected. Therefore, functional symbioses, with their peculiarities in different MCRs (different microbiota composition in different Mediterranean zones), 
represent an opportunity to understand complex molecular interactions at the interface between crop/soil/climate and have great potential as a strategy for agriculture adaptation/mitigation.

\section{Economic and Social Impact and Farmer Adaptation}

Agriculture is the main land user and largest water consumer across large areas of the MCRs [103], and is also an important source of income and employment, and thus the economic and social perspectives associated with CC are crucial for understanding the sustainability of farming systems. A number of studies have reported economic and social impacts of CC worldwide, including impacts on welfare, income, and gender inequality [112-114], and migration and agricultural productivity [115-117]. Studies conducted in MCRs have shown impacts on the value of ecosystem services [118], but most importantly on crop productivity $[3,55,103,118,119]$.

The implementation of adaptation practices at the farm level is an effective way to reduce the impacts of CC and to increase agricultural productivity. For example, in Nepal, small-holders adopting a larger number of adaptation practices were on average 13\% more efficient than those adopting fewer practices [120]. Also, in Central Chile, adaptation practices, in particular improvements in irrigation, had positive effects on productivity [121]. This highlights the relevance of CC adaptation to farmers' productivity and enriches discussions of the need to implement adaptation practices. However, despite the specific and global impacts, the rate of adaptation to CC is still low [121,122]. In addition, it has been noticed that there is a divergence between the adaptation practices recommended by experts and those adopted by farmers. This indicates that it is not only important to generate adaptation technologies but also to understand the factors associated with the ability to adapt, as well as to develop effective strategies for transferring such technologies to farmers [123]. The urgency of this matter leaves open questions about the factors that might limit or encourage adaptation practices [124-128].

Understanding farmers' behavior towards adaptation practices requires a broad view of different approaches that include public policy, economics, geography, sociology and psychology, as well as different layers of analysis. Moreover, decisions are dynamic processes that require a temporal and cross-sectional analysis [129]. From an economic perspective there is an agreement that production scale, access to credit, costs, and benefits, among others, have a positive impact on adaptation $[126,127,130]$. From the field of psychology, perceptions and motivational aspects become relevant drivers. Farmers' own perceptions about CC, which are affected by access to information and socio-demographic characteristics [131], also shape adaptation decisions. As Pashen and Ison [132] argue, "how we understand the environment is how we behave", so more attention has been focused on the farmer's perception of CC. According to Raymond and Spoehr [133], farmers that accept the concept of CC worked on adaptation responses within their farms, such as increasing their water storage capacity, in contrast to those that reject the phenomenon. The literature also shows that, in general, farmers perceive the changes in climate variables differently depending on their location $[123,134-136]$. The above makes clear that a target for public policy is to create and transfer knowledge to farmers so they can move towards making informed decisions [137]. Other psychological aspects within the decision to adapt as an individual cognitive process, such as beliefs, values, and attitudes, have been demonstrated to be relevant in the farmer's decision to adapt [138,139].

However, the view of CC has surpassed the concept of an individual process. As Ostrom [140] recognized, global environmental problems are a common good that affects and is affected by everyone. Along these lines, several studies have approached CC through collective actions to increase cooperation in implementing practices that reduce farmers' uncertainty [140-143]. Strong governance structures with effective (achieving the desired goals) and efficient (optimal allocation of public resources) policy incentives can favor adaptation among famers. Hence, public policies should not only provide specific individual incentives to adaptation, but also provide incentives to construct networks, systems of innovation and institutional arrangements that aim to create a favorable environment. It has been acknowledged that the ability of society to confront CC and reduce the vulnerability of 
agro-socio-economic systems will depend on the adaptive capacity of its stakeholders, as politics are embedded in a society facing environmental challenges [126,127,144-146].

Adaptation to CC has been recognized to be a nascent domain of public policy, thus it still requires a large amount of information and knowledge for its comprehension, planning, and management [147]. Understanding the context, drivers of farmers decisions toward adaptation, and the role of stakeholders is the first step towards identifying effective policy instruments [122]. The literature has recognized that investing in research, especially in plant breeding and simulation models of climate scenarios, could be a powerful tool to develop adaptive capacity [137]. Additionally, it is necessary to improve water resource management by strengthening the water infrastructure and water distribution system [148].

Various strategies of adaptation in agriculture have been discussed, but uncertainty about the impacts and effectiveness of these adaptations on producers in MCRs will continue [17]. Nonetheless, in light of CC projections, it is important that producers develop resilience in their production and social systems. Improving technologies, seeds and agronomic practices to cope with climatic uncertainty is one side of adapting to CC. It is also necessary to have a deep and multidisciplinary understanding of the factors that drives individuals' adaptation decisions, and to provide the effective incentives to change behavior towards adaptation to CC. Understanding the individual motivations, perceptions, knowledge networks, barriers, risk aversion, and financial constraints provide evidence on which to base the development of public policy, with the expectation that adaptation rates will increase.

\section{Perspectives and Concluding Remarks}

This review has revealed the urgent need of linking science and policy design to increase adaptation, as well as the importance of knowing the impacts of CC and adaption strategies to achieve effective results at the farm level. Some authors argue that intensive agricultural systems could be more resistant and better adapted to adverse climatic conditions $[103,149]$, which would be an advantage for MCRs where large-scale farming is common. Nevertheless, we need to take into account not only the productive outcomes, but also the social, economic, and environmental components as determinants for persistence of agricultural systems. Despite the increased consensus on this matter, there are still questions as to how well prepared and sustainable these agricultural systems will be in the face of CC. However, more severe CC could lead to geographical shift of cropping areas and farming systems.

Water has always been considered the most critical resource for sustainable development of agriculture in most Mediterranean countries [127]. Mediterranean agriculture has been developed under the concept of higher productivity with less water, which is why traditional cereal crops, olive trees, and vineyards are, for the most part, tolerant to drought stress, having adapted to long dry seasonal periods [15]. Considering the forecasts, the demand for water will increase in all areas due to increases in crop evapotranspiration [103], and the supply of water resources will be even more unstable due to decreased precipitation in the future. Therefore, it is necessary to continue research on adapting crops and novel technologies to enhance water productivity and ameliorate the negative effects faced by farmers. In fact, there are still many questions that should be resolved such as those related to decreasing climatic uncertainty as well as the strategies deployed by crops and farmers to cope with the environmental and socio-economic consequences imposed by CC in MCRs.

From the point of view of food security, humans are currently challenged by an increasing global population that demands more food, the desire for environmentally and socially sustainable food production, and how to create food distribution networks and avoid food waste that will ensure no further deaths from starvation [150]. Under these pressures, MCRs have been earmarked to produce a significant amount of food despite their small area, globally. This underscores the urgent need for investing in research, development and innovations in MCRs as well as understanding the socio-economic impacts in these Mediterranean zones so that global food demands can be secured in the next few years. As investment in agricultural research and development has proven to be an effective way of stopping food crises, the lack of integrative approaches in responding to agricultural constraints has endangered productivity [151]. The implementation of research clusters composed 
of multidisciplinary groups of scientists, extensionists, and local farmers, with the explicit aim of translating scientific information into biotechnological solutions, will certainly aid this goal. In addition, the generation of high quality information related to the variation in climate factors, strategies of adaptation, and impacts on farmers could provide suitable and useful material for decision-makers to generate proper policies to face the challenges imposed by CC.

Author Contributions: N.B.-S., S.O.-F., and C.A.-O. developed the section on climate change effects. G.A.L., M.A.M.-M., and A.d.-P. developed the section about adaptation of agriculture to climate change. A.E. and R.J.-R. worked on the section of economic and social impact and farmer adaptation. A.d.-P., A.E., and M.A.M.-M. performed the final editing and the perspectives and concluding remarks.

Funding: This research was funded by the grant PIEI "Adaptación de la Agricultura al Cambio Climático (A2C2)", Universidad de Talca.

Conflicts of Interest: The authors declare no conflict of interest.

\section{References}

1. Underwood, E.C.; Viers, J.H.; Klausmeyer, K.R.; Cox, R.L.; Shaw, M.R. Threats and biodiversity in the Mediterranean biome. Divers. Distrib. 2009, 15, 188-197. [CrossRef]

2. Giorgio, F.; Lionello, P. Climate change projections for the Mediterranean region. Glob. Planet. Chang. 2008, 63, 90-104. [CrossRef]

3. IPCC. Climate Change 2014: Mitigation of Climate Change. Contribution of Working Group III to the Fifth Assessment Report of the Intergovernmental Panel on Climate Change; Cambridge University Press, Cambridge: Cambridge, UK, 2014.

4. Polade, S.D.; Gershunov, A.; Cayan, D.R.; Dettinger, M.D.; Pierce, D.W. Precipitation in a warming world: Assessing projected hydro-climate changes in California and other Mediterranean climate regions. Sci. Rep. 2017, 7, 10783. [CrossRef] [PubMed]

5. Blanco-Canqui, H.; Lal, R. Cropping Systems. In Principles of Soil Conservation and Management; Springer: Dordrecht, The Netherlands, 2010.

6. Klein, R.J.; Maciver, D.C. Adaptation to climate variability and change: Methodological issues. Mitig. Adapt. Strat. Glob. 1999, 4, 189-198. [CrossRef]

7. United Nation. Paris Agreement. 2015. Available online: https://unfccc.int/sites/default/files/english_paris_ agreement.pdf (accessed on 8 May 2019).

8. Thrall, P.H.; Oakeshott, J.G.; Fitt, G.; Southerton, S.; Burdon, J.J; Sheppard, A.; Russell, R.J.; Zalucki, M.; Heino, M.; Denison, R.F. Evolution in agriculture: The application of evolutionary approaches to the management of biotic interactions in agro-ecosystems. Evol. Appl. 2011, 4, 200-215. [CrossRef]

9. Trigo, R.M.; Xoplaki, E.; Zorita, E.; Lüterbacher, J.; Krichak, S.O.; Alpert, P.; Jacobeit, J.; Sáenz, J.; Fernández, J.; González-Rouco, J.F.; et al. Relations between variability in the Mediterranean region and mid-latitude variability. In Mediterranean Climate Variability; Lionello, P., Malanotte-Rizzoli, P., Boscolo, R., Eds.; Elsevier: Amsterdam, The Netherlands, 2006; pp. 179-226.

10. Niedzielski, T. El Niño/Southern Oscillation and Selected Environmental Consequences. Adv. Geophys. 2014, $55,1-46$.

11. Kelley, C.; Mohtadi, S.; Cane, M.A.; Seager, R.; Kushnir, Y. Climate change in the Fertile Crescent and implications of the recent Syrian drought. Proc. Natl. Acad. Sci. USA 2015, 112, 3241-3246. [CrossRef]

12. Valverde, P.; Carvalho, M.; Serralheiro, R.; Maia, R.; Ramos, V.; Oliveira, B. Climate change impacts on rainfed agriculture in the Guadiana river basin (Portugal). Agric. Water Manag. 2015, 150, 35-45. [CrossRef]

13. Guiot, J.; Cramer, W. Climate change: The 2015 Paris Agreement thresholds and Mediterranean basin ecosystems. Science 2016, 354, 465-468. [CrossRef]

14. Garreaud, R.; Alvarez-Garreton, C.; Barichivich, J.; Boisier, J.P.; Christie, D.; Galleguillos, M.; LeQuesne, C.; McPhee, J.; Zambrano-Bigiarini, M. The 2010-2015 mega drought in Central Chile: Impacts on regional hydroclimate and vegetation. Hydrol. Earth Syst. Sci. 2017, 21, 6307-6327. [CrossRef]

15. García-Ruiz, J.M.; López-Moreno, J.I.; Vicente-Serrano, S.M.; Lasanta, T.; Beguería, S. Mediterranean water resources in a global scenario. Earth-Sci. Rev. 2011, 105, 121-139. [CrossRef] 
16. Williams, C.J.R. Climate Change in Chile: An analysis of state-of-the-art observations, satellite-derived estimates and climate model simulations. J. Earth Sci. Clim. Chang. 2017, 8, 400. [CrossRef]

17. Challinor, A.J.; Watson, J.; Lobell, D.B.; Howden, S.M.; Smith, D.R.; Chhetri, N. A meta-analysis of crop yield under climate change and adaptation. Nat. Clim. Chang. 2014, 4, 287-291. [CrossRef]

18. Lesk, C.; Rowhani, P.; Ramankutty, N. Influence of extreme weather disasters on global crop production. Nature 2016, 529, 84-87. [CrossRef]

19. Tanasijevic, L.; Todorovic, M.; Pereira, L.S.; Pizzigalli, C.; Lionello, P. Impacts of climate change on olive crop evapotranspiration and irrigation requirements in the Mediterranean region. Agric. Water Manag. 2014, 144, 54-68. [CrossRef]

20. Lobos, G.A.; Hancock, J.F. Breeding blueberries for a changing global environment: A review. Front. Plant Sci. 2015, 6, 782. [CrossRef]

21. Van Leeuwen, C.; Darriet, P. The impact of climate change on viticulture and wine quality. J. Wine Econ. 2016, 11, 150-167. [CrossRef]

22. Daryanto, S.; Wang, L.; Jacinthe, P.A. Global synthesis of drought effects on cereal, legume, tuber and root crops production: A review. Agric. Water Manag. 2017, 179, 18-33. [CrossRef]

23. Blum, A. Effective use of water (EUW) and not water use efficiency (WUE) is the target of crop yield improvement under drought stress. Field Crop. Res. 2009, 112, 119-123. [CrossRef]

24. Dolferus, R.; Powell, N.; Ji, X.; Ravash, R.; Edlington, J.; Oliver, S.; van Dongen, J.; Sshiran, B. Chapter 8: The physiology of reproductive-stage abiotic stress tolerance in cereals. In Molecular Stress Physiology of Plants; Rout, G., Das, A., Eds.; Springer: New Delhi, India, 2013; pp. 193-218.

25. del Pozo, A.; Yáñez, A.; Matus, I.A.; Tapia, G.; Castillo, D.; Sanchez-Jardón, L.; Araus, J.L. Physiological traits associated with wheat yield potential and performance under water-stress in a Mediterranean environment. Front. Plant Sci. 2016, 7, 987. [CrossRef]

26. Farooq, M.; Gogoi, N.; Barthakur, S.; Baroowa, B.; Bharadwaj, N.; Alghamdi, S.S.; Siddique, K.H.M. Drought stress in grain legumes during reproduction and grain filling. J. Agron. Crop Sci. 2016, 203, 81-102. [CrossRef]

27. Monneveux, P.; Rekika, D.; Acevedo, E.; Merah, O. Effect of drought on leaf gas exchange, carbon isotope discrimination, transpiration efficiency and productivity in field grown durum wheat genotypes. Plant Sci. 2006, 170, 867-872. [CrossRef]

28. Araus, J.L.; Slafer, G.A.; Royo, C.; Serret, M.D. Breeding for yield potential and stress adaptation in cereals. Crit. Rev. Plant Sci. 2008, 27, 377-412. [CrossRef]

29. Tambussi, E.A.; Bort, J.; Nogués, S.; Guiamet, J.J.; Araus, J.L. The photosynthetic role of ears in C3 Cereals: Metabolism, water use efficiency and contribution to grain yield. Crit. Rev. Plant Sci. 2007, 26, 1-16. [CrossRef]

30. Maydup, M.; Antonietta, M.; Guiamet, J.; Tambussi, E. The contribution of green parts of the ear to grain filling in old and modern cultivars of bread wheat (Triticum aestivum L.): Evidence for genetic gains over the past century. Field Crop. Res. 2012, 134, 208-215. [CrossRef]

31. Yang, J.; Zhang, J. Grain filling of cereals under soil drying. New Phytol. 2006, 169, 223-236. [CrossRef] [PubMed]

32. Ehdaie, B.; Alloush, G.A.; Waines, J.G. Genotypic variation in linear rate of grain growth and contribution of stem reserves to grain yield in wheat. Field Crop. Res. 2008, 106, 34-43. [CrossRef]

33. Dreccer, M.F.; Herwaarden, A.F.; Chapman, S.C. Grain number and grain weight in wheat lines contrasting for stem water soluble carbohydrate concentration. Field Crop. Res. 2009, 112, 43-54. [CrossRef]

34. Yañez, A.; Tapia, G.; Guerra, F.; del Pozo, A. Stem carbohydrate dynamics and expression of genes involved in fructan accumulation and remobilization during grain growth in wheat (Triticum aestivum L.) genotypes with contrasting tolerance to water stress. PLoS ONE 2017, 12, e0177667. [CrossRef]

35. Davies, S.L.; Turner, N.C.; Palta, J.A.; Siddique, K.H.M.; Plummer, J.A. Remobilisation of carbon and nitrogen supports seed filling in chickpea subjected to water deficits. Aust. J. Agric. Res. 2000, 51, 855-866. [CrossRef]

36. Oury, V.; Tardieu, F.; Turc, O. Ovary apical abortion under water deficit is caused by changes in sequential development of ovaries and in silk growth rate in maize. Plant Physiol. 2016, 171, 986-996. [CrossRef]

37. García-Tejero, I.; Romero-Vicente, R.; Jiménez-Bocanegra, J.A.; Martínez-García, G.; Durán-Zuazo, V.H.; Muriel-Fernández, J.L. Response of citrus trees to deficit irrigation during different phenological periods in relation to yield, fruit quality, and water productivity. Agric. Water Manag. 2010, 97, 689-699. [CrossRef] 
38. Pérez-Pastor, A.; Ruiz-Sánchez, M.C.; Domingo, D. Effects of timing and intensity of deficit irrigation on vegetative and fruit growth of apricot trees. Agric. Water Manag. 2014, 134, 110-118. [CrossRef]

39. Myburgh, P.A. Responses of Vitis vinifera L. cv. Sultanina to water deficits during various pre- and post-harvest phases under semi-arid conditions. S. Afr. J. Enol. Vitic. 2003, 24, 25-33. [CrossRef]

40. Acevedo-Opazo, C.; Ortega-Farias, S.; Fuentes, S. Effects of grapevine (Vitis vinifera L.) water status on water consumption, vegetative growth and grape quality: An irrigation scheduling application to achieve regulated deficit irrigation. Agric. Water Manag. 2010, 97, 956-964. [CrossRef]

41. Rahmati, M.; Davarynejad, G.H.; Génard, M.; Bannayan, M.; Azizi, M.; Vercambre, G. Peach water relations, gas exchange, growth and shoot mortality under water deficit in semi-arid weather conditions. PLoS ONE 2015, 1, e0120246. [CrossRef]

42. Romero, P.; Gil-Muñoza, R.; Fernández-Fernández, J.I.; del Amor, F.M.; Martínez-Cutillas, A.; García-García, J. Improvement of yield and grape and wine composition in field-grown Monastrell grapevines by partial root zone irrigation, in comparison with regulated deficit irrigation. Agric. Water Manag. 2015, 149, 55-73. [CrossRef]

43. Herrera, J.C.; Bucchetti, B.; Sabbatini, P.; Comuzzo, P.; Zulini, L.; Vecchione, A.; Peterlunger, E.; Castellarin, S.D. Effect of water deficit and severe shoot trimming on the composition of Vitis vinifera L. Merlot grapes and wines. Aust. J. Grape Wine Res. 2015, 21, 254-265. [CrossRef]

44. Ripoll, J.; Urban, L.; Brunel, B.; Bertin, N. Water deficit effects on tomato quality depend on fruit developmental stage and genotype. J. Plant Physiol. 2016, 190, 26-35. [CrossRef] [PubMed]

45. Fereres, E.; Orgaz, F.; Gonzalez-Dugo, V.; Testi, L.; Villalobos, F.J. Balancing crop yield and water productivity tradeoffs in herbaceous and woody crops. Funct. Plant Biol. 2014, 41, 1009-1018. [CrossRef]

46. Hasanuzzaman, M.; Nahar, K.; Alam, M.D.M.; Roychowdhury, R.; Fujita, M. Physiological, biochemical, and molecular mechanisms of heat stress tolerance in plants. Int. J. Mol. Sci. 2013, 14, 9643-9684. [CrossRef]

47. Fischer, R.A.; Byerlee, D.; Edmeades, G.O. Crop Yields and Global Food Security: Will Yield Increase Continue to Feed the World? ACIAR Monograph No. 158; Australian Centre for International Agricultural Research: Canberra, Australia, 2014; p. xxii. 660p.

48. Bita, C.E.; Gerats, T. Plant tolerance to high temperature in a changing environment: Scientific fundamentals and production of heat stress-tolerant crops. Front. Plant Sci. 2013, 4, 273. [CrossRef]

49. Hatfield, J.L.; Prueger, J.H. Temperature extremes: Effect on plant growth and development. Weather Clim. Extrem. 2015, 10, 4-10. [CrossRef]

50. Trnka, M.; Olesen, J.E.; Kersebaum, K.C.; Skjelvag, A.O.; Eitzinger, J.; Seguin, B.; Peltonen-Sainio, P.; Rotter, R.; Iglesias, A.; Orlandini, S.; et al. Agroclimatic conditions in Europe under climate change. Glob. Chang. Biol. 2011, 17, 2298-2318. [CrossRef]

51. Howden, S.M.; Soussana, J.F.; Tubiello, F.N.; Chhetri, N.; Dunlop, M.; Meinke, H. Adapting agriculture to climate change. Proc. Natl. Acad. Sci. USA 2007, 104, 19691-19696. [CrossRef]

52. Jones, P.D.; Lister, D.H.; Jaggard, K.W.; Pidgeon, J.D. Future climate impact on the productivity of sugar beet (Beta vulgaris L.) in Europe. Clim. Chang. 2003, 58, 93-108. [CrossRef]

53. Lavalle, C.; Micale, F.; Houston, T.D. Climate change in Europe. Impact on agriculture and forestry. A review. Agron. Sustain. Dev. 2009, 29, 433-446. [CrossRef]

54. Quiroga, S.; Iglesias, A. A comparison of the climate risks of cereal, citrus, grapevine and olive production in Spain. Agric. Syst. 2009, 101, 91-100. [CrossRef]

55. Iglesias, A.; Quiroga, S.; Schlickenrieder, J. Assessing uncertainty to support climate change adaptation needs for Mediterranean crops. Clim. Res. 2010, 44, 83-94. [CrossRef]

56. Meza, F.J.; Silva, D.; Vigil, H. Climate change impacts on irrigated maize in Mediterranean climates: Evaluation of double cropping as an emerging adaptation alternative. Agric. Syst. 2008, 98, 21-30. [CrossRef]

57. El Yaacoubi, A.; Malagi, G.; Oukabli, M.; Hafidi, M.; Legave, J.M. Global warming impact on floral phenology of fruit trees species in Mediterranean region. Sci. Hort. 2014, 180, 243-253. [CrossRef]

58. Legave, J.M.; Guédon, Y.; Malagi, G.; El Yaacoubi, A.; Bonhomme, M. Differentiated Responses of Apple Tree Floral Phenology to Global Warming in Contrasting Climatic Regions. Front. Plant Sci. 2015, 6, 1054. [CrossRef]

59. Santos, J.A.; Costa, R.; Fraga, H. Climate change impacts on thermal growing conditions of main fruit species in Portugal. Clim. Chang. 2017, 140, 273-286. [CrossRef] 
60. Webb, L. The Impact of Greenhouse Gas-Induced Climate Change on the Australian Wine Industry. Ph.D. Thesis, School of Agriculture and Food Systems, University of Melbourne, Parkville Victoria, Australia, 2006; p. 277. Available online: http://eprints.infodiv.unimelb.edu.au/archive/00003030/ (accessed on 8 May 2019).

61. Webb, L.B.; Whetton, P.H.; Barlow, E.W.R. Modelled impact of future climate change on the phenology of winegrapes in Australia. Aust. J. Grape Wine Res. 2007, 13, 165-175. [CrossRef]

62. Lobell, D.B.; Gourdji, S.M. The Influence of climate change on global crop productivity. Plant Physiol. 2012, 160, 1686-1697. [CrossRef] [PubMed]

63. Borrás, L.; Slafer, G.A. Agronomy and plant breeding are key to combating food crisis. Nature 2008, 453, 1177. [CrossRef]

64. Lehmann, N.; Finger, R.; Klein, T.; Calanca, P.; Walter, A. Adapting crop management practices to climate change: Modeling optimal solutions at the field scale. Agric. Syst. 2013, 117, 55-65. [CrossRef]

65. Bodner, G.; Nakhforoosh, A.; Kaul, H.P. Management of crop water under drought: A review. Agron. Sustain. Dev. 2015, .35, 401-442. [CrossRef]

66. Dessaux, I.; Grandclément, C.; DenisFaure, D. Engineering the rhizosphere. Trends Plant Sci. 2016, 21, 266-278. [CrossRef]

67. Camargo, A.V.; Lobos, G.A. Latin America: A development pole for phenomics. Front. Plant Sci. 2016, 7, 1729. [CrossRef]

68. Richards, R.A.; Rebetzke, G.J.; Condon, A.G.; Herwaarden, A.F.V. Breeding Opportunities for increasing the efficiency of water use and crop yield in temperate cereals. Crop Sci. 2002, 42, 111-121. [CrossRef]

69. Furbank, R.T.; Tester, M. Phenomics-technologies to relieve the phenotyping bottleneck. Trends Plant Sci. 2011, 16, 635-644. [CrossRef] [PubMed]

70. Yang, W.; Guo, Z.; Huang, C.; Duan, L.; Chen, G.; Jiang, N.; Fang, W.; Feng, H.; Xie, W.; Lian, X.; et al. Combining high-throughput phenotyping and genome-wide association studies to reveal natural genetic variation in rice. Nat. Commun. 2014, 5, 5087. [CrossRef]

71. Großkinsky, D.K.; Svensgaard, J.; Christensen, S.; Roitsch, T. Plant phenomics and the need for physiological phenotyping across scales to narrow the genotype-to-phenotype knowledge gap. J. Exp. Bot. 2015, 66, 5429-5440. [CrossRef]

72. Rahaman, M.M.; Chen, D.; Gillani, Z.; Klukas, C.; Chen, M. Advanced phenotyping and phenotype data analysis for the study of plant growth and development. Front. Plant Sci. 2015, 6, 619. [CrossRef] [PubMed]

73. Porter, J.R.; Christensen, S. Deconstructing crop processes and models via identities. Plant Cell Environ. 2013, 36, 1919-1925. [CrossRef]

74. Tuberosa, R.; Turner, N.C.; Cakir, M. Two decades of InterDrought conferences: Are we bridging the genotype-to-phenotype gap? J. Exp. Bot. 2014, 65, 6137-6139. [CrossRef]

75. Fischer, R.A. Understanding the physiological basis of yield potential in wheat. J. Agric. Sci. 2007, 145, 99-113. [CrossRef]

76. Cattivelli, L.; Rizza, F.; Badeck, F.W.; Mazzucotelli, E.; Mastrangelo, A.M.; Franci, E.; Marè, C.; Tondelli, A.; Stanca, A.M. Drought tolerance improvement in crop plants: An integrated view from breeding to genomics. Field Crop. Res. 2008, 105, 1-14. [CrossRef]

77. Fleury, D.; Jefferies, S.; Kuchel, H.; Langridge, P. Genetic and genomic tools to improve drought tolerance in wheat. J. Exp. Bot. 2010, 61, 3211-3222. [CrossRef]

78. Ghanem, M.E.; Marrou, H.; Sinclair, T.R. Physiological phenotyping of plants for crop improvement. Trends Plant Sci. 2015, 20, 139-144. [CrossRef]

79. Reynolds, M.; Langridge, P. Physiological breeding. Curr. Opin. Plant Biol. 2016, 31, 162-171. [CrossRef]

80. Wang, W.X.; Vinocur, B.; Altman, A. Plant responses to drought, salinity and extreme temperatures: Towards genetic engineering for stress tolerance. Planta 2003, 218, 1-14. [CrossRef]

81. Diab, A.A.; Teulat, B.; This, D.; Ozturk, N.Z.; Benscher, D.; Sorrells, M.E. Identification of drought-inducible genes and differentially expressed sequence tags in barley. Theor. Appl. Genet. 2004, 109, 1417-1425. [CrossRef]

82. Tondelli, A.; Francia, E.; Barabaschi, D.; Aprile, A.; Skinner, J.S.; Stockinger, E.J.; Stanca, A.M.; Pecchioni, N. Mapping regulatory genes as candidates for cold and drought stress tolerance in barley. Theor. Appl. Genet. 2006, 112, 445-454. [CrossRef]

83. Dhont, S.; Wuyts, N.; Inzé, D. Cell to whole-plant phenotyping: The best is yet to come. Trends Plant Sci. 2013, 18, 428-439. [CrossRef] 
84. Houle, D.; Govindaraju, D.R.; Omholt, S. Phenomics: The next challenge. Nat. Rev. Genet. 2010, 11, 855-866. [CrossRef]

85. Brennan, J.P.; Condon, A.G.; Van Ginkel, M.; Reynolds, M.P. An economic assessment of the use of physiological selection for stomatal aperture-related traits in the CIMMYT wheat breeding programme. J. Agric. Sci. 2007, 145, 187-194. [CrossRef]

86. Reynolds, M.; Manes, Y.; Izanloo, A.; Langridge, P. Phenotyping approaches for physiological breeding and gene discovery in wheat. Ann. Appl. Biol. 2009, 155, 309-320. [CrossRef]

87. Zalidis, G.; Stamatiadis, S.; Takavakoglou, V.; Eskridge, K.; Misopolinos, N. Impacts of agricultural practices on soil and water quality in the Mediterranean region and proposed assessment methodology. Agric. Ecosyst. Environ. 2002, 88, 137-146. [CrossRef]

88. Stone, L.; Schlegel, A. Tillage and crop rotation phase effects on soil physical properties in the west-central Great Plains. Agron. J. 2010, 102, 483-491. [CrossRef]

89. Brunel, N.; Seguel, O.; Acevedo, E. Conservation tillage and water availability for wheat in the interior dryland of Central Chile. J. Soil Sci. Plant Nutr. 2013, 13, 622-637. [CrossRef]

90. Bescansa, P.; Imaza, M.J.; Virto, I.; Enrique, A.; Hoogmoed, W.B. Soil water retention as affected by tillage and residue management in semiarid Spain. Soil Tillage Res. 2006, 87, 19-27. [CrossRef]

91. Lampurlanés, J.; Plaza-Bonilla, D.; Álvaro-Fuentes, J.; Cantero-Martínez, C. Long-term analysis of soil water conservation and crop yield under different tillage systems in Mediterranean rainfed conditions. Field Crop. Res. 2016, 189, 59-67. [CrossRef]

92. Alvarez, R.; Steinbach, H. A review of the effects of tillage systems on some soil physical properties, water content, nitrate availability and crops yield in the Argentine Pampas. Soil Tillage Res. 2009, 104, 1-15. [CrossRef]

93. Fuentes, M.; Govaerts, B.; de León, F.; Hidalgo, C.; Dendooven, L.; Sayre, K.; Etchevers, J. Fourteen years of applying zero and conventional tillage, crop rotation and residue management systems and its effect on physical and chemical soil quality. Eur. J. Agron. 2009, 30, 228-237. [CrossRef]

94. Brunel-Saldias, N.; Martínez, I.; Seguel, O.; Ovalle, C.; Acevedo, E. Structural characterization of a compacted alfisol under different tillage systems. J. Soil Sci. Plant Nutr. 2016, 16, 689-701. [CrossRef]

95. Sang, X.; Wang, D.; Lin, X. Effects of tillage practices on water consumption characteristics and grain yield of winter wheat under different soil moisture conditions. Soil Tillage Res. 2016, 163, 185-194. [CrossRef]

96. Wang, X.; Cai, D.; Hoogmoed, W.; Oenema, O.; Perdok, U. Developments in conservation tillage in rainfed regions of North China. Soil Tillage Res. 2007, 93, 239-250. [CrossRef]

97. Hatfield, J.L. Soil Management for Increasing Water Use Efficiency in Field Crops under Changing Climates; Publications from USDA-ARS/UNL Faculty; U.S. Department of Agriculture, Agricultural Research Service: Lincoln, NE, USA, 2011. Available online: http://digitalcommons.unl.edu/usdaarsfacpub/1376 (accessed on 8 May 2019).

98. Elliott, J.; Deryng, D.; Müller, C.; Frieler, K.; Konzmann, M.; Gerten, D.; Glotter, M.; Flörke, M.; Wada, Y.; Best, N.; et al. Constraints and potentials of future irrigation water availability on agricultural production under climate change. Proc. Natl. Acad. Sci. USA 2014, 111, 3239-3244. [CrossRef]

99. Malek, Z.; Verburg, P.H. Mediterranean land systems: Representing diversity and intensity of complex land systems in a dynamic region. Landsc. Urban Plan. 2017, 165, 102-116. [CrossRef]

100. Sowers, J.; Vengosh, A.; Weinthal, E. Climate change, water resources, and the politics of adaptation in the Middle East and North Africa. Clim. Chang. 2010, 104, 599-627. [CrossRef]

101. Passioura, J. The drought environment: Physical, biological and agricultural perspectives. J. Exp. Bot. 2007, 58, 113-117. [CrossRef]

102. Chai, Q.; Gan, Y.; Zhao, C.; Xu, H.L.; Waskom, R.M.; Niu, Y.; Siddique, K.H.M. Regulated deficit irrigation for crop production under drought stress. A review. Agron. Sustain. Dev. 2016, 36, 3. [CrossRef]

103. Iglesias, A.; Mougou, R.; Moneo, M. Towards adaptation of agriculture to climate change in the Mediterranean. Reg. Environ. Chang. 2011, 11, 159-166. [CrossRef]

104. Brundrett, M.; Bougher, N.; Dell, B.; Grove, T.; Malajczuk, N. (Eds.) Working with Mycorrhizas in Forestry and Agriculture; ACIAR Monograph 32: Canberra, Australia, 2006; p. 374.

105. Babikova, Z.; Gilbert, L.; Bruce, T.J.; Birkett, M.; Caulfield, J.C.; Woodcock, C.; Pickett, J.A.; Johnson, D. Underground signals carried through common mycelial networks warn neighbouring plants of aphid attack. Ecol. Lett. 2013, 16, 835-843. [CrossRef] 
106. Brachmann, A.; Parniske, M. The Most Widespread Symbiosis on Earth. PLoS Biol. 2005, 4, e239. [CrossRef]

107. Trappe, J.M.A. Frank and mycorrhizae: The challenge to evolutionary and ecologic theory. Mycorrhiza 2005, 15, 277-281. [CrossRef]

108. Molina-Montenegro, M.A.; Oses, R.; Torres-Díaz, C.; Atala, C.; Núñez, M.A.; Armas, C. Fungal endophytes associated with roots of nurse cushion species have positive effects on native and invasive beneficiary plants in an alpine ecosystem. Perspect. Plant Ecol. Syst. 2015, 17, 218-226. [CrossRef]

109. Smith, S.; Read, D. Mycorrhizal Symbiosis, 3rd ed.; Academic Press: Berlin, Germany, 2008.

110. Molina-Montenegro, M.A.; Oses, R.; Torres-Díaz, C.; Atala, C.; Zurita-Silva, A.; Ruíz-Lara, S. Antarctic root-endophytes improve the ecophysiological performance and production of fresh biomass in lettuce plants under drought condition. AoB Plants 2016, 8, plw064. [CrossRef]

111. Kumar, S.; Singh, A. Biopesticides for Integrated Crop Management: Environmental and Regulatory Aspects. J. Biofertil. Biopestic. 2014, 5, e121.

112. Burke, M.; Hsiang, S.M.; Miguel, E. Global non-linear effect of temperature on economic production. Nature 2015, 527, 235-239. [CrossRef] [PubMed]

113. Eastin, J. Climate change and gender equality in developing states. World Dev. 2018, 107, 289-305. [CrossRef]

114. Keerthiratne, S.; Tol, R.S.J. Impact of natural disasters on income inequality in Sri Lanka. World Dev. 2018, 105, 217-230. [CrossRef]

115. Lobell, D.B.; Field, C.B.; Cahill, K.N.; Bonfils, C. Impacts of future climate change on California perennial crop yields: Model projections with climate and crop uncertainties. Agric. For. Meteorol. 2006, 141, 208-218. [CrossRef]

116. Deressa, T.T.; Hassan, R.M. Economic impact of climate change on crop production in Ethiopia: Evidence from cross-section measures. J. Afr. Econ. 2009, 18, 529-554. [CrossRef]

117. Mukherjee, D.; Bravo-Ureta, B.; De Vries, A. Dairy productivity and climatic conditions: Econometric evidence from South-eastern United States. Aust. J. Agric. Resour. Econ. 2012, 57, 123-140. [CrossRef]

118. Fleischer, A.; Sternberg, M. The Economic Impact of Global Climate Change on Rangeland Ecosystem-The Space-for-Time Approach. Ecol. Econ. 2006, 59, 287-295. [CrossRef]

119. Ponti, L.; Gutierrez, A.P.; Ruti, P.M.; Dell'Aquila, A. Fine-scale ecological and economic assessment of climate change on olive in the Mediterranean Basin reveals winners and losers. Proc. Natl. Acad. Sci. USA 2014, 111, 5598-5603. [CrossRef]

120. Khanal, U.; Wilso, C.; Lee, B.; Hoang, V.N. Do climate change adaptation practices improve technical efficiency of smallholder farmers? Evidence from Nepal. Clim. Chang. 2018, 147, 507-521. [CrossRef]

121. Roco, L.; Engler, A.; Bravo-Ureta, B.; Jara-Rojas, R. The impact of climatic change adaptation on agricultural productivity in Central Chile: A stochastic production frontier approach. Sustainability 2017, 9, 1648. [CrossRef]

122. Mees, H.L.; Dijk, J.; van Soest, D.; Driessen, P.P.; van Rijswick, M.H.; Runhaar, H. A method for the deliberate and deliberative selection of policy instrument mixes for climate change adaptation. Ecol. Soc. 2014, 19, 58. [CrossRef]

123. Roco, L.; Engler, A.; Bravo-Ureta, B.; Jara-Rojas, R. Farm level adaptation decisions to face climatic change and variability: Evidence from Central Chile. Environ. Sci. Policy 2014, 44, 86-96. [CrossRef]

124. Di Falco, S.; Veronesi, M.; Yesuf, M. Does adaptation to climate change provide food security? A micro-perspective from Ethiopia. Am. J. Agric. Econ. 2011, 93, 829-846. [CrossRef]

125. Tambo, J.A.; Abdoulaye, T. Climate change and agricultural technology adoption: The case of drought tolerant maize in rural Nigeria. Mitig. Adapt. Strat. 2012, 17, 277-292. [CrossRef]

126. Biesbroek, G.R.; Klostermann, J.E.M.; Termeer, C.J.A.M.; Kabat, P. On the nature of barriers to climate change adaptation. Reg. Environ. Chang. 2013, 13, 1119-1129. [CrossRef]

127. Chartzoulakis, K.; Bertaki, M. Sustainable water management in agriculture under climate change. Agric. Agric. Sci. Procedia 2015, 4, 88-98. [CrossRef] 
128. Kalafatis, S.E.; Lemos, M.C.; Lo, Y.J.; Frank, K.A. Increasing information usability for climate adaptation: The role of knowledge networks and communities of practice. Glob. Environ. Chang. 2015, 32, 30-39. [CrossRef]

129. Feola, G.; Lerner, A.M.; Jain, M.; Montefrio, M.J.F.; Nicholas, K.A. Researching farmer behaviour in climate change adaptation and sustainable agriculture: Lessons learned from five case studies. J. Rural Stud. 2015, 39, 74-84. [CrossRef]

130. Wood, S.A.; Jina, A.S.; Jain, M.; Kristjanson, P.; DeFries, R.S. Smallholder farmer cropping decisions related to climate variability across multiple regions. Glob. Environ. Chang. 2014, 25, 163-172. [CrossRef]

131. Gbetibouo, G.A. Understanding Farmers' Perceptions and Adaptations to Climate Change and Variability: The Case of the Limpopo Basin, South Africa; IFPRI Discuss Paper 00849; IFPRI: Washington, DC, USA, 2009.

132. Paschen, J.A.; Ison, R. Narrative research in climate change adaptation - Exploring a complementary paradigm for research and governance. Res. Policy 2014, 43, 1083-1092. [CrossRef]

133. Raymond, C.; Spoehr, J. The acceptability of climate change in agricultural communities: Comparing responses across variability and change. J. Environ. Manag. 2013, 115, 69-77. [CrossRef]

134. Sofoluwe, N.; Tijane, A.; Baruwa, O. Farmers' perception and adaptation to climate change in Osun State, Nigeria. Afr. J. Agric. Res. 2011, 6, 4789-4794.

135. Chaudhary, P.; Rai, S.; Wangdi, S.; Mao, A.; Rehman, N.; Chettri, S.; Bawa, K. Consistency of local perceptions of climate change in the Kangchenjunga Himalaya landscape. Curr. Sci. 2011, 101, 504-513.

136. Manandhar, S.; Vogt, D.S.; Perret, S.R.; Kazama, F. Adapting cropping systems to climate change in Nepal: A cross-regional study of farmers' perception and practices. Reg. Environ. Chang. 2011, 11, 335-348. [CrossRef]

137. Asseng, S.; Pannell, D.J. Adapting dryland agriculture to climate change: Farming implications and research and development needs in Western Australia. Clim. Chang. 2013, 118, 167-181. [CrossRef]

138. Truelove, H.B.; Carrico, A.R.; Thabrew, L. A socio-psychological model for analyzing climate change adaptation: A case study of Sri Lankan paddy farmers. Glob. Environ. Chang. 2015, 31, 85-97. [CrossRef]

139. Feng, X.; Liu, M.; Huo, X.; Ma, W. What Motivates Farmers' Adaptation to Climate Change? The Case of Apple Farmers of Shaanxi in China. Sustainability 2017, 9, 519. [CrossRef]

140. Ostrom, E. Polycentric systems for coping with collective action and global environmental change. Glob. Environ. Chang. 2010, 20, 550-557. [CrossRef]

141. Adger, W.N. Social Capital, Collective Action, and Adaptation to Climate Change. Econ. Geogr. 2003, 79, 387-404. [CrossRef]

142. Montaña, E.; Diaz, H.P.; Hurlbert, M. Development, local livelihoods, and vulnerabilities to global environmental change in the South American Dry Andes. Reg. Environ. Chang. 2016, 16, 2215-2228. [CrossRef]

143. Salvini, G.; van Paassen, A.; Ligtenberg, A.; Carrero, G.C.; Bregt, A.K. A role-playing game as a tool to facilitate social learning and collective action towards Climate Smart Agriculture: Lessons learned from Apuí, Brazil. Environ. Sci. Policy 2016, 63, 113-121. [CrossRef]

144. Kongsager, R. Barriers to the Adoption of Alley Cropping as a Climate-Smart Agriculture Practice: Lessons from Maize Cultivation among the Maya in Southern Belize. Forests 2017, 8, 260. [CrossRef]

145. Zilberman, D.; Zhao, J.; Heiman, A. Adoption versus adaptation, with emphasis on climate change. Annu. Rev. Resour. Econ. 2012, 4, 27-53. [CrossRef]

146. Wise, R.M.; Fazey, I.; Stafford Smith, M.; Park, S.E.; Eakin, H.C.; Archer Van Garderen, E.R.M.; Campbell, B. Reconceptualising adaptation to climate change as part of pathways of change and response. Glob. Environ. Chang. 2014, 28, 325-336. [CrossRef]

147. Eriksen, S.H.; Nightingale, A.J.; Eakin, H. Reframing adaptation: The political nature of climate change adaptation. Glob. Environ. Chang. 2015, 35, 523-533. [CrossRef]

148. Dewulf, A. Contrasting frames in policy debates on climate change adaptation. Wires Clim. Chang. 2013, 4, 321-330. [CrossRef]

149. Reidsma, P.; Ewert, F.; Boogaard, H.; van Diepen, K. Regional crop modelling in Europe: The impact of climatic conditions and farm characteristics on maize yields. Agric. Syst. 2009, 100, 51-60. [CrossRef] 
150. Godfray, H.C.J.; Crute, I.R.; Haddad, L.; Lawrence, D.; Muir, J.F.; Nisbett, N.; Pretty, J.; Robinson, S.; Toulmin, C.; Whiteley, R. The future of the global food system. Philos. Trans. R. Soc. B 2010, 365, 2769-2777. [CrossRef]

151. Ray, D.K.; Mueller, N.D.; West, P.C.; Foley, J.A. Yield trends are insufficient to double global crop production by 2050. PLoS ONE 2013, 8, e66428. [CrossRef] 